\title{
Child psychiatry: A scientometric analysis 1980-2016 [version
}

\section{1; peer review: 3 approved]}

\author{
Sadiq Naveed ${ }^{1}$, Ahmed Waqas (i)2, Salman Majeed ${ }^{3}$, Muhammad Zeshan ${ }^{4}$, \\ Nusrat Jahan ${ }^{1}$, Muhammad Haaris Sheikh ${ }^{5}$
}

${ }^{1}$ KVC Prairie Ridge Psychiatric Hospital, Kansas City, KS, USA

${ }^{2} \mathrm{CMH}$ Lahore Medical College \& Institute of Dentistry, Lahore Cantt, Pakistan

${ }^{3}$ Pennsylvania State Milton S. Hershey Medical Center, Harrisburg, PA, USA

${ }^{4}$ Bronx-Lebanon Hospital Center, South Bronx, NY, USA

${ }^{5}$ King Edward Medical University, Lahore, Pakistan

V1 First published: 01 Aug 2017, 6:1293

https://doi.org/10.12688/f1000research.12069.1

Latest published: 01 Aug 2017, 6:1293

https://doi.org/10.12688/f1000research.12069.1

\section{Abstract}

Background: The field of child and adolescent psychiatry lags behind adult psychiatry significantly. In recent years, it has witnessed a significant increase in the publication of journals and articles. This study provides a detailed bibliometric analysis of articles published from 1980 to 2016, in the top seven journals of child and adolescent psychiatry.

Methods: Using the Web of Science core collection, we selected 9,719 research papers published in seven psychiatric journals from 1980 to 2016. We utilized the Web of Science Analytics tool and Network Analysis Interface for Literature Studies (NAILS) Project scripts to delineate the general trends of publication in these journals. Then, cocitation analysis and hierarchical cluster analysis was performed using CiteSpace to map important papers, landmark theories and foci of research in child and adolescent psychiatry.

Results: The field of child and adolescent psychiatry has experienced an increasing trend in research, which was reflected in the results of this study. Hierarchical cluster analysis revealed that the research foci in psychiatry were primarily studies related to the design of psychometric instruments, checklists, taxonomy, attention deficit hyperactivity disorder (ADHD), depression, PTSD, social phobia, and psychopharmacology. Moreover, several landmark studies, including the validation of a child behavior checklist, Ainsworth's empirical evidence of Bowlby's attachment theory, and adult outcomes of childhood dysregulation were published. This study also reports rapid expansion and innovation in research areas in the field of child and adolescent psychiatry from 1980-2016.

Conclusions: Rapid expansion and innovation in research areas in the field of child and adolescent psychiatry has been observed, from 1980 to 2016.

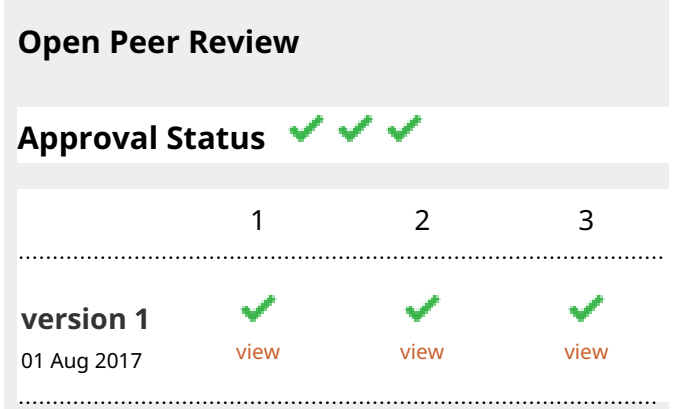

1. Miyuru Chandradasa (iD), University of Kelaniya, Ragama, Sri Lanka Colombo North Teaching Hospital, Ragama, Sri Lanka

Layani Champika, Latrobe Regional Hospital, Traralgon, Australia

2. Muhammad Waqar Azeem, Weill Cornell Medical College in Qatar, Doha, Qatar

3. Deepa Mishra, McMaster University, Hamilton, Canada

Any reports and responses or comments on the article can be found at the end of the article. 


\section{Keywords}

evolution, scientometrics, bibliometric, citespace, child psychiatry,

influential, publication output

Corresponding author: Ahmed Waqas (ahmedwaqas1990@hotmail.com)

Author roles: Naveed S: Conceptualization, Data Curation, Writing - Original Draft Preparation, Writing - Review \& Editing; Waqas A: Conceptualization, Data Curation, Formal Analysis, Writing - Original Draft Preparation; Majeed S: Writing - Original Draft Preparation, Writing - Review \& Editing; Zeshan M: Writing - Original Draft Preparation, Writing - Review \& Editing; Jahan N: Visualization, Writing Original Draft Preparation, Writing - Review \& Editing; Haaris Sheikh M: Writing - Original Draft Preparation, Writing - Review \& Editing

Competing interests: No competing interests were disclosed.

Grant information: The author(s) declared that no grants were involved in supporting this work.

Copyright: ( 2017 Naveed S et al. This is an open access article distributed under the terms of the Creative Commons Attribution License, which permits unrestricted use, distribution, and reproduction in any medium, provided the original work is properly cited. Data associated with the article are available under the terms of the Creative Commons Zero "No rights reserved" data waiver (CC0 1.0 Public domain dedication).

How to cite this article: Naveed S, Waqas A, Majeed S et al. Child psychiatry: A scientometric analysis 1980-2016 [version 1; peer review: 3 approved] F1000Research 2017, 6:1293 https://doi.org/10.12688/f1000research.12069.1

First published: 01 Aug 2017, 6:1293 https://doi.org/10.12688/f1000research.12069.1 


\section{Introduction}

Mental health disorders are very prevalent among children and adolescents, resulting in a significant impact on society. It is estimated that $13-20 \%$ of children living in the United States (1 out of 5 children) suffer from a mental disorder every year, resulting in an annual economic loss of 247 billion USD ${ }^{1}$. Despite these statistics, the field of child psychiatry has attracted a little research interest as compared to other specialties of medicine. This is evident from the fact that not even a single article related to mental health among children was published in the first 45 years of the publication history of American Journal of Insanity ${ }^{2}$. In a clinical context, the first ever hospital specializing in the treatment of sick children; La'Hôpital des Enfants-Malades, was established in 1802 on the Rue deSévres in Paris. It was also the first time that the field of pediatrics was recognized as an established specialty of medicine ${ }^{2}$. Institutions specializing in mental health of children, however, did not develop until after World War I, when August Hamberger established his outpatient clinic in the University of Heidelberg ${ }^{3}$. Experts believe that child psychiatry evolved as a separate field after America's first juvenile court was established in $1899^{4}$. Then, during World War II, Great Britain started to patronize the psychological development of its children, for a better future ${ }^{5}$. Similar strides were made in the US, when President Harry Truman declared war on mental illness in 1946, after signing the National Mental Health Act that led to the birth of the National Institute of Mental Health ${ }^{6}$. This resulted in an explosion of research in understanding the nature of psychiatric diseases, its diagnoses and taxonomy and psychopharmacological and behavioral treatments. At present, child and adolescent psychiatry has established itself as a distinct specialty globally, however, major disparities exist between the developed and third world countries? ${ }^{7}$.

While the development of infrastructure and facilities in any field of medicine are important, scientific research, new discoveries and influential publications are the true marker that ensure its constant progress and evolution. The history of research and development in child psychiatry is quite intricate; spanning discoveries in several domains of medical and social sciences. It is very important to map the research output in a field, to help guide policy makers, researchers and funding agencies towards areas where restriction or increase in research activity is required. In recognition of its importance, several reproducible statistical methods were developed under the umbrella of scientometrics. It is the "quantitative study of science, communication in science, and science policy", helping to evaluate the impact of journals, scientists and institutes on the development and innovation of a scientific field ${ }^{8}$.

The present study analyzes the trends of research in the field of child and adolescent psychiatry by employing reproducible scientometric techniques. Although several scientometric studies have been published in general psychiatry ${ }^{9,10}$ and other fields of medicine, there is a paucity of such studies mapping the research output in the field of child psychiatry, hence warranting this study. The present study identifies influential publications, landmark theories, authors, countries and major funding agencies contributing to child psychiatry from 1980-2016.

\section{Methods}

For the purpose of this scientometric analysis, we selected seven journals (Table 1) indexed under the term "Child Psychiatry" in Google Scholar. These journals were selected on the base of their ISI impact factor, h5-index and h5-median, following the methodology of previous scientometric articles published in the field of psychiatry $^{9,10}$. The Web of Science core collection was utilized to download bibliographic records of articles published in these journals from 1980-2016 to provide an overview of recent advances in this field. These records included title, author names, abstract, key words and cited references. This search was performed in December, 2016 and records for a total of 9,719 articles, published during 1980- June 2016 were retrieved. There were no restrictions based on type or language of articles included in this analyses.

This study utilized three software tools for analyses of data; Web of Science core collection records, Network Analysis Interface for Literature Studies (NAILS) Project scripts ${ }^{11}$ and Citespace (v4.0 R5, Drexel University, Pennsylvania, USA) ${ }^{12}$. The Web of Science core collection-online analysis platform was used to document journal wise influential authors, institutions, funding agencies and countries. NAILS software was utilized to analyze these to identify the most cited keywords in these journals.

CiteSpace (v4.0 R5, Drexel University, Pennsylvania, USA) is a Java-based platform that allows knowledge mapping by visualization of bibliographic data and hence it is a popular and user-friendly tool to perform co-citation analyses ${ }^{12}$. According to the theory

\begin{tabular}{|c|c|c|c|}
\hline Journal & H5-index & H5-Median & Impact factor \\
\hline $\begin{array}{l}\text { Journal of Child Psychology and } \\
\text { Psychiatry }\end{array}$ & 67 & 101 & 6.615 \\
\hline $\begin{array}{l}\text { Journal of the American Academy of } \\
\text { Child \& Adolescent Psychiatry }\end{array}$ & 67 & 97 & 7.182 \\
\hline European Child \& Adolescent Psychiatry & 41 & 67 & 3.339 \\
\hline Child Psychiatry \& Human Development & 26 & 45 & 1.839 \\
\hline $\begin{array}{l}\text { Child and Adolescent Psychiatric Clinics } \\
\text { of North America }\end{array}$ & 24 & 32 & 1.590 \\
\hline Clinical Child Psychology and Psychiatry & 21 & 28 & 1.192 \\
\hline $\begin{array}{l}\text { Child and Adolescent Psychiatry and } \\
\text { Mental Health }\end{array}$ & 20 & 31 & 2.134 \\
\hline
\end{tabular}


of document co-citation ${ }^{13,14}$, co-citation relationships between two documents exist when they are cited together by another document.

Using "time slicing", the bibliographic records were divided into four groups according to the year of publication; 1980-1990, 1991-2000, 2001-2010 and 2011-2016, the year per slice was set to 1 with each year represented by top 50 articles based on the number of citations. The 'team source' selects were 'title', 'abstract', 'author keywords' and 'keywords plus' and the 'node types' selected were 'cited reference'.

Network analyses were run with the link reduction method using pathfinder network scaling and then, bibliographic records for each 10-year slice were visualized separately. Articles were represented as nodes and lines as edges. Using this technique, several key results could be identified, such as new theories/concepts related to a field (visualized as a purple ring), centrality reflecting the status of a publication in their network/field, citation bursts (hot topics of research), citation tree rings representing year-wise citation pattern of a node (article). Articles with centrality values $>0.1$ were considered as significant entities controlling significant resources in their collaborative networks. Based on these techniques, researchers can observe and understand bibliographic trends in order to identify patterns of research in particular fields and regularities of citations in particular time periods ${ }^{15}$.

\section{Results}

General trends of publication and citation output

A total of 9, 719 research papers were published in the seven psychiatric journals 'Journal of Child Psychology and Psychiatry', 'Journal of the American Academy of Child \& Adolescent Psychiatry', 'European Child \& Adolescent Psychiatry', 'Child Psychiatry \& Human Development', 'Child and Adolescent Psychiatric Clinics of North America', 'Clinical Child Psychology and Psychiatry', and 'Child and Adolescent Psychiatry and Mental Health' (Table 1), from 1980 to June 2016. All journals publish multidisciplinary research articles in the fields of child and adolescent psychiatry, ensuring constant improvement and evolution of the field toward a cutting-edge, evidence-based clinical specialty.

Figure 1 shows the yearly publication volume in the field of child and adolescent psychiatry since 1980, and documents the rapid increase in publication volume in this field since the 1980s. The publication output in these journals rose from less than a 100 journal articles in 1980 to more than 500 in 2015. Figure 2 shows the yearly trend in the number of citations received by articles included in our analyses. The articles were cited a total of 1,37,006 times, however, this number dropped to 1,27,119 after removing selfcitations. The total number of articles citing these publications was 81551 (77853 after excluding self-citations). Average citations per item were 16.85 , contributing to an h-index of 132 .

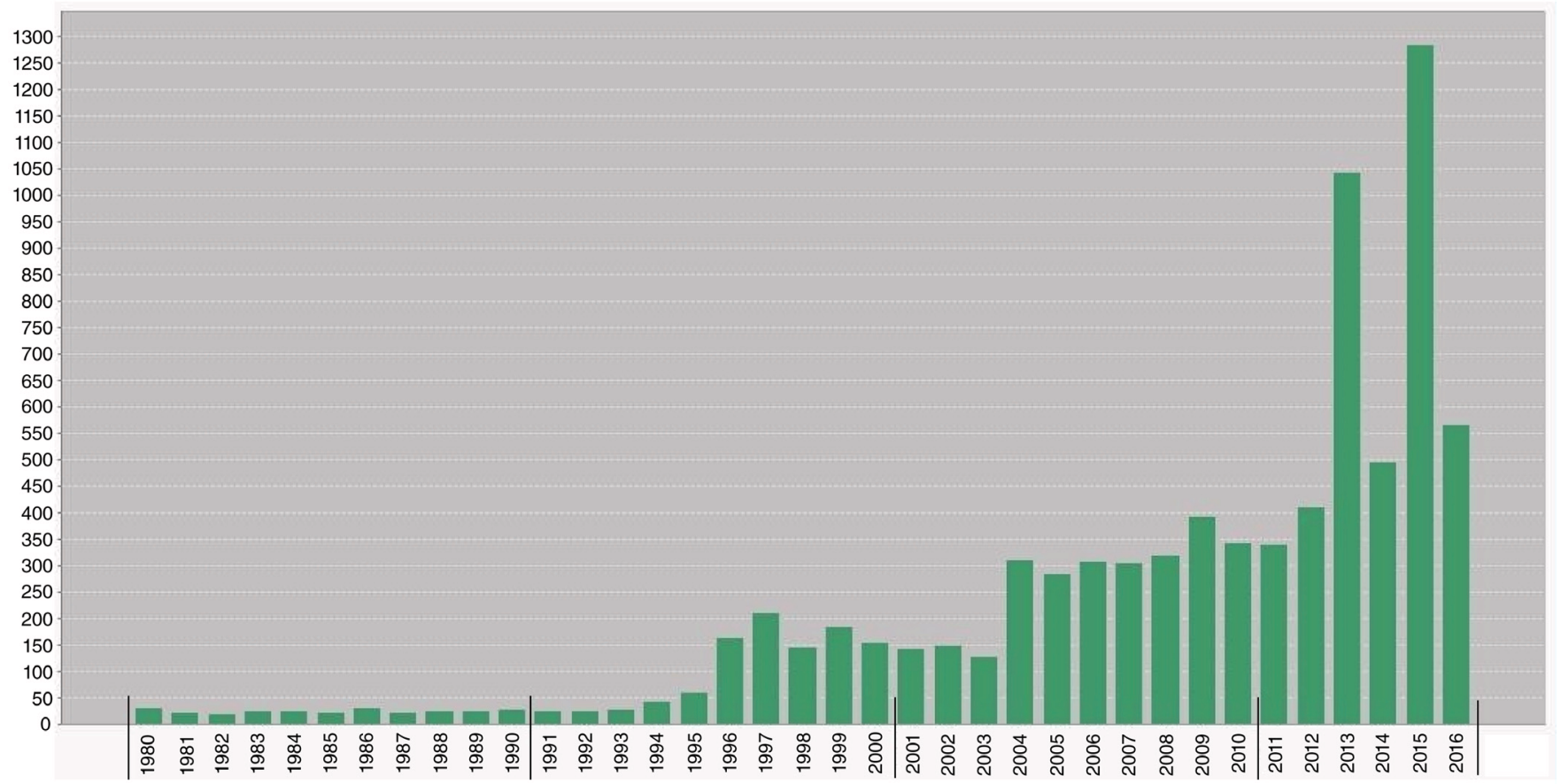

Figure 1. Publication output of child psychiatry journals included in present analyses, from 1980-2016. 


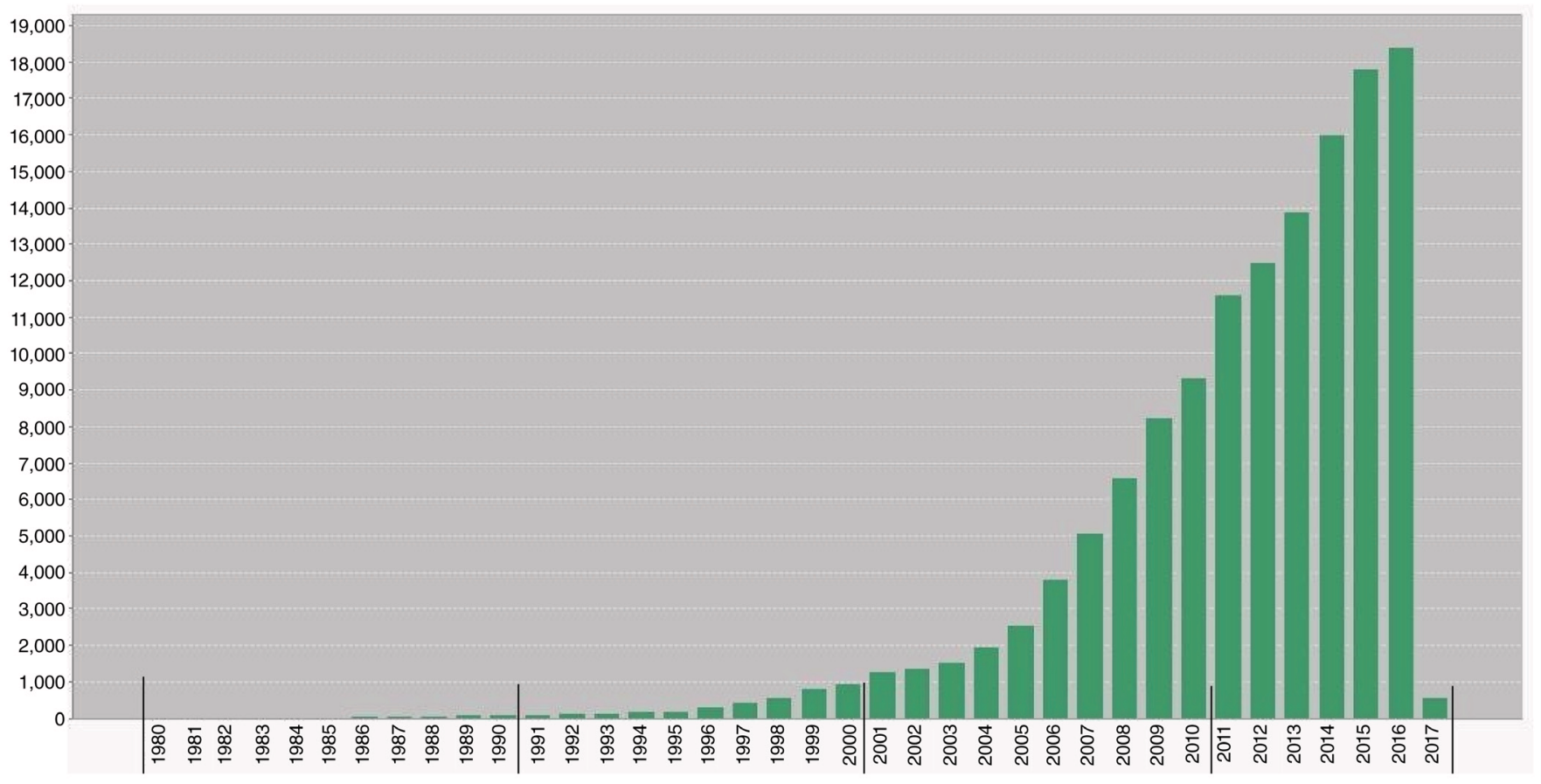

Figure 2. Trend of number of citations received by research articles published in the top seven journals of child and adolescent psychiatry from 1980-2016.

The increasing trend in publication ensures that the field of child psychiatry is constantly evolving because of new discoveries in epidemiology, assessment techniques, genetics, neurosciences and therapeutics. However, the research output in journals related to child psychiatry still lags behind those of general psychiatry and other specialties of medicine ${ }^{16}$.

\section{Top institutions, authors and countries}

It is interesting to note that the highest output of research in child psychiatry comes from institutions in developed countries. According to Albayrak et al., this regional disparity is attributed to a high GDP of these countries, higher funding available and availability of more public health resources, specialty training programs and mental health professionals committed to the field of child psychiatry ${ }^{7}$. In addition, regions like South Asia, and a high percentage of developing European countries $(23 \%)$ do not have training programs in child psychiatry, hence, low research output ${ }^{7}$. Similar trends were identified in our study. According to the Web of Science (core database) citation report for these seven journals, countries with highest research output were USA, England, Netherlands, Germany, Spain, Canada, Australia, Sweden, Switzerland and Norway. Globally, the most productive organizations were University of London, Kings College London, Yale University, University of California, University College, London, Harvard University, Pensylvania Commonwealth System of Higher Education, Vrije Universiteit Amsterdam, Radboud University Nijmegen and the University of Pittsburgh in USA (Table 2).

\section{Most cited keywords from 1980 to 2016}

According to our analysis, the top foci of research in child psychiatry correspond with most common mental health conditions globally. Figure 3 details the top cited keywords, representing the top foci of research in these selected journals (Figure 3). Top cited psychopathologies were depression, attention deficit hyperactivity disorder (ADHD), autism, anxiety, conduct disorder, obsessive compulsive disorder, post-traumatic stress disorder, bipolar disorder, suicide and aggression. This is in accordance with Polanzcyk et al., who identified the worldwide prevalence of any anxiety disorder to be $6.5 \%$, any depressive disorder to be $2.6 \%$, ADHD to be $3.4 \%$, and any disruptive disorder to be $5.7 \%{ }^{17}$. Methylphenidate was identified as the top cited keyword for a drug used in child psychiatry. Our results are in accordance with López Muñoz et al., who reported methylphenidate to be the most researched drug for attention deficit hyperactivity disorder (ADHD), also correlating it with an increased trend in its use ${ }^{18}$.

\section{Publications from 1980 to 1990}

In further analysis, CiteSpace was used to identify important articles based on their centrality values. Articles with centrality values $>0.1$ were considered significant. These articles were considered important within their collaborative network, focused on a specific research domain (Table 3, Figure 4). Visualization of these clusters also helped in identification of purple nodes that represent important and groundbreaking theories, and represent a link between two different clusters ${ }^{12}$. 
Table 2. Top organizations, countries and authors from 1980-2016 $(n=8,131)$.

\begin{tabular}{|c|c|c|c|c|c|}
\hline $\begin{array}{l}\text { Most Productive } \\
\text { author }\end{array}$ & $\mathbf{n}$ & Country & $\mathbf{n}$ & Organization & $\mathbf{n}$ \\
\hline Buitelaar JK & 113 & USA & 3216 & University of London & 698 \\
\hline Rothenberger A & 78 & England & 1337 & Kings College London & 478 \\
\hline Verhulst FC & 76 & Netherlands & 651 & Yale University & 290 \\
\hline Sonuga-Barke EJS & 70 & Germany & 567 & $\begin{array}{l}\text { University College } \\
\text { London }\end{array}$ & 287 \\
\hline Coghill D & 66 & Spain & 375 & University of California & 267 \\
\hline Banaschewski T & 62 & Canada & 353 & Harvard University & 247 \\
\hline Steinhuasen $\mathrm{HC}$ & 59 & Australia & 312 & $\begin{array}{l}\text { Pensylvania } \\
\text { Commonhealth System } \\
\text { of Higher Education }\end{array}$ & 199 \\
\hline Gillberg C & 48 & Sweden & 257 & $\begin{array}{l}\text { Vrije Universiteit } \\
\text { Amsterdam }\end{array}$ & 151 \\
\hline Rutter M & 48 & Switzerland & 214 & $\begin{array}{l}\text { Radboud University } \\
\text { Nijmegen }\end{array}$ & 148 \\
\hline Butter M & 48 & Norway & 206 & University of Pittsburgh & 140 \\
\hline
\end{tabular}

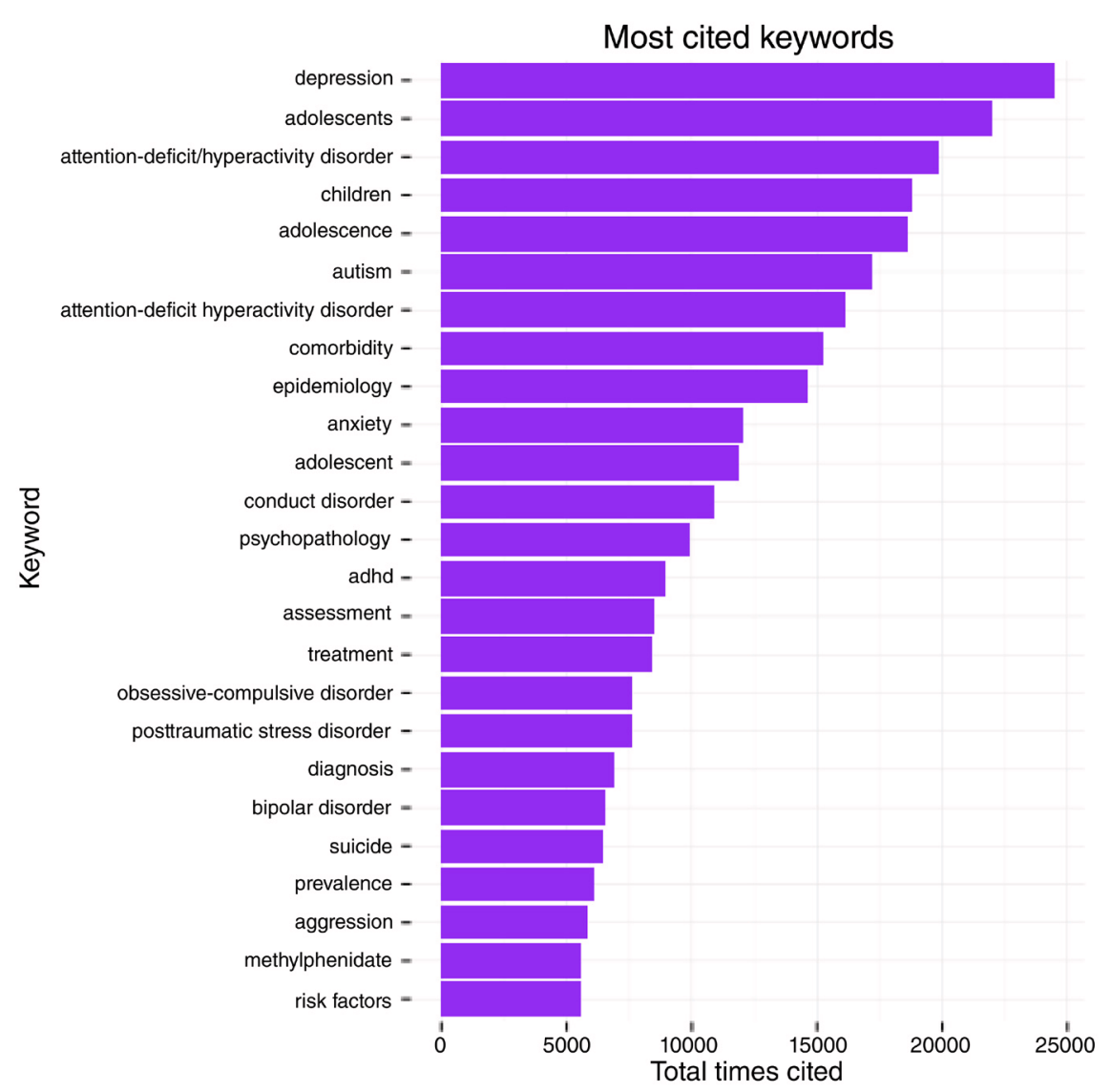

Figure 3. Most cited keywords in the research articles published in journals included in the present analysis. 
Table 3. Top articles with centrality values $\geq 0.1$ or purple rings $(1980-1990)$.

\begin{tabular}{|c|c|c|c|}
\hline Reference & $\begin{array}{l}\text { Centrality } \\
\text { value }\end{array}$ & Title & $\begin{array}{l}\text { Purple } \\
\text { node }\end{array}$ \\
\hline $\begin{array}{l}\text { Carlson and } \\
\text { Cantwel (1980) }\end{array}$ & 0.42 & $\begin{array}{l}\text { Unmasking masked depression in children and } \\
\text { adolescents }\end{array}$ & Yes \\
\hline $\begin{array}{l}\text { Shaffer D et al. } \\
\text { (1983) }\end{array}$ & 0.31 & A children's global assessment scale (CGAS) & Yes \\
\hline Carroll BJ (1980) & 0.24 & Testing communicative performance: An interim study & No \\
\hline $\begin{array}{l}\text { Gaensbauer and } \\
\text { Sands (1979) }\end{array}$ & 0.23 & $\begin{array}{l}\text { Distorted affective communications in abused/neglected } \\
\text { infants and their potential impact on caretakers }\end{array}$ & Yes \\
\hline $\begin{array}{l}\text { Achenbach } \\
(1980)\end{array}$ & 0.22 & $\begin{array}{l}\text { DSM-III in light of empirical research on the classification } \\
\text { of child psychopathology. }\end{array}$ & Yes \\
\hline $\begin{array}{l}\text { Egeland and } \\
\text { Sroufe (1981) }\end{array}$ & 0.21 & Attachment and early maltreatment & Yes \\
\hline $\begin{array}{l}\text { Ainsworth et al. } \\
(1978)\end{array}$ & 0.18 & $\begin{array}{l}\text { Patterns of attachment: A psychological study of the } \\
\text { strange situation }\end{array}$ & Yes \\
\hline Cantwell (1978) & 0.15 & Hyperactivity and antisocial behavior. & Yes \\
\hline $\begin{array}{l}\text { Achenbach } \\
\text { (1983) }\end{array}$ & 0.12 & $\begin{array}{l}\text { Manual for the child behavior checklist and revised child } \\
\text { behavior profile. }\end{array}$ & Yes \\
\hline $\begin{array}{l}\text { Lewis et al. } \\
\text { (1979) }\end{array}$ & 0.1 & $\begin{array}{l}\text { Violent juvenile delinquents: Psychiatric, neurological, } \\
\text { psychological, and abuse factors }\end{array}$ & Yes \\
\hline
\end{tabular}
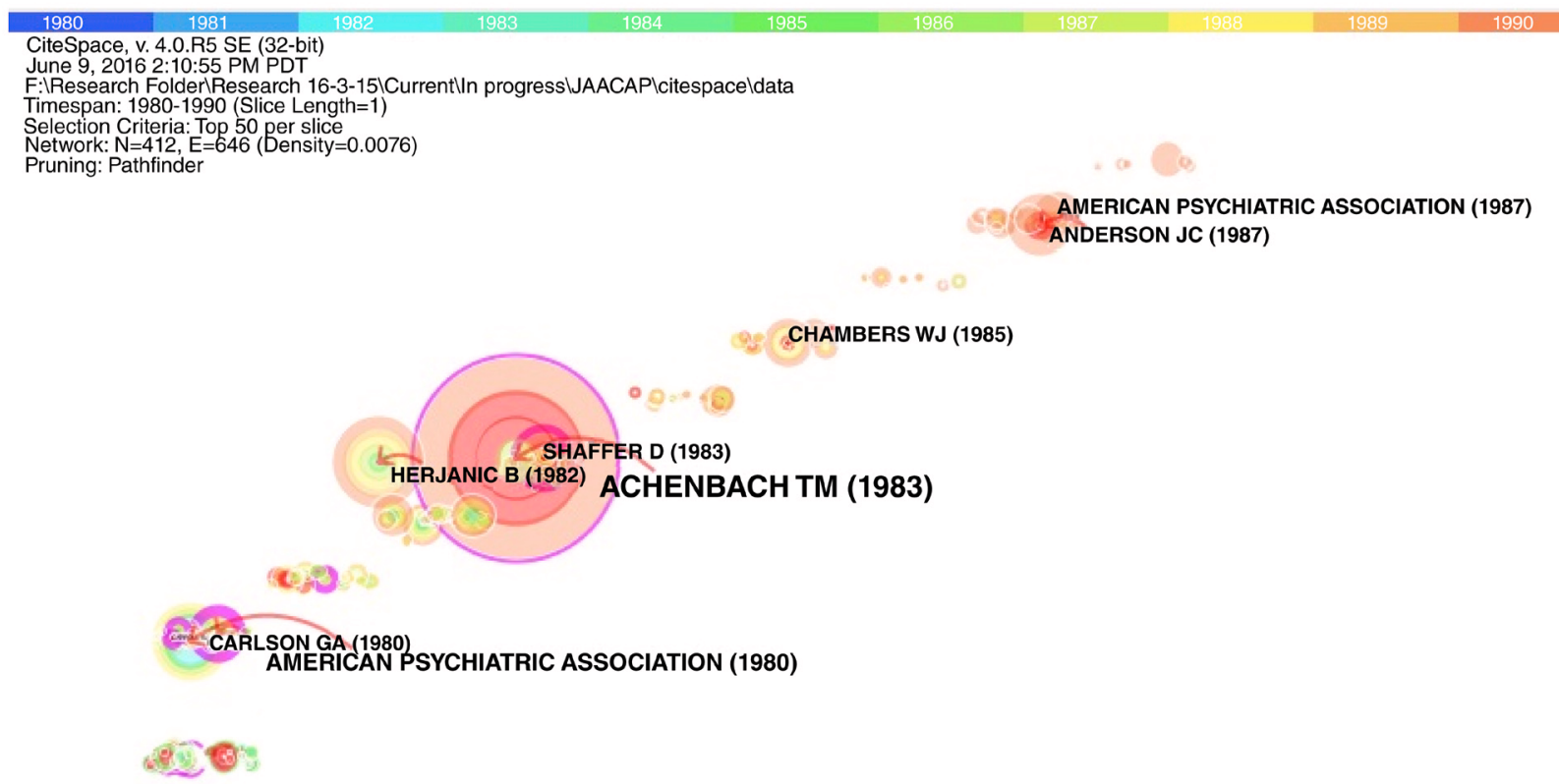

Figure 4. Visualization of important nodes from 1980-1990. Figure 4 represents a visual co-citation network of 412 research documents published in the field of child psychiatry from 1980-1990. The rings represent several key results such as new theories/concepts related to a field (visualized as a purple ring), centrality reflecting the status of a publication in their network/field, and citation tree rings representing year-wise citation pattern of an article.

From 1980-1990, there were 412 nodes (articles) and 646 edges (co-citation links). The most important paper with a centrality value of 0.42 (identified as a purple node) was titled, "diagnostic significance of masked depression", by Carlson \& Cantwell ${ }^{19}$. It was a landmark study in the field of child psychiatry as it elucidated the diagnostic significance of unmasking depression in adolescents who presented with other comorbidities and symptoms. Cantwell reviewed the evidence linking hyperactivity with antisocial behavior in the youth, and Lewis et al. compared the neuropsychiatric, intellectual, and educational status of extremely violent and less violent incarcerated boys $\mathrm{s}^{20,21}$.

Development of questionnaires and rating scales specific to child psychiatry is another milestone in its history. Like any other scientific discipline, this allowed researchers and clinicians to reliably quantify emotional problems among children and 
adolescents. This also helps them to track symptoms and response to the treatment ${ }^{22}$. During this decade, two important rating scales were developed, subsequently influencing research in child psychiatry. Shaffer et al.'s 'Children's Global Assessment Scale' adapted the adult version of Global Assessment Scale, to evaluate overall functioning among children, as a complement to their clinical diagnoses ${ }^{23}$. Similarly, Achenbach 's exploration of DSM-III in perspective of child psychopathology lead to the development Child Behavior Checklist that integrates information from a variety of sources; parent, child and teacher ${ }^{24,25}$.

Other important publications explored the relationship between the caretakers and the child. Bowlby's attachment theory propounded that a child initially forms only one attachment relationship, and this attachment figure becomes a base for all future relationships ${ }^{26}$ and disrupting this, can lead to long term consequences. Ainsworth's studies provided the first empirical evidence of Bowlby's attachment theory ${ }^{26}$, which was subsequently explored in a longitudinal study by Egeland and Sroufe ${ }^{27}$. In a similar context, Gaensbauer \& Sands' study on the therapeutic relationship between abused/neglected infants and their caretakers, which concluded that personality traits of the child may contribute to disturbance in caretaker-infant interaction, leading to abuse and neglect ${ }^{28}$. All of these studies represented significant between-ness centrality in this time period.
Publications from 1991 to 2000

There were 315 nodes and 508 edges in this time period (Table 4, Figure 5). In recent decades, the integration of epidemiological evidence into child psychiatry, has truly helped it reach its scientific potential. This specific discipline helped child psychiatry in three principal ways: a) identify the burden of childhood psychiatric illnesses b) identify new risk factors for psychiatric illnesses and c) explore the validity and reliability of diagnostic statistical manual.

During this period, several landmark epidemiological studies were conducted. There were three studies focusing on suicide, PTSD and ADHD. The most important paper with a centrality value of 0.34 , identified as a purple node was entitled, "Risk factors for adolescent suicide: a comparison of adolescent suicide victims with suicidal inpatients" by Brent et al. ${ }^{29}$. It identified the most prevalent risk factors for suicidal behaviors in adolescents and emphasized on their proper identification. Pynoos et al.'s work on acute PTSD garnered a lot of attention during this period. He concluded that these symptoms were not affected by age, gender and ethnicity and that severity of acute PTSD symptoms correlated with proximity to violence ${ }^{30}$. Barkley et al. identified hyperactivity as a pattern of behavioral symptom that is highly stable over time and associated with considerably greater risk for family disturbance and negative academic and social outcomes in adolescence ${ }^{31}$.

Table 4. Top articles with centrality values $\geq 0.1$ or purple rings $1991-2000$.

\begin{tabular}{|c|c|c|c|}
\hline Reference & $\begin{array}{l}\text { Centrality } \\
\text { value }\end{array}$ & Basic theme & $\begin{array}{l}\text { Purple } \\
\text { node }\end{array}$ \\
\hline Brent et al. (1988) & 0.34 & $\begin{array}{l}\text { Risk factors for adolescent suicide: a comparison of adolescent suicide } \\
\text { victims with suicidal inpatients }\end{array}$ & Yes \\
\hline Anderson et al. (1987) & 0.31 & $\begin{array}{l}\text { DSM-III disorders in preadolescent children: Prevalence in a large sample } \\
\text { from the general population }\end{array}$ & Yes \\
\hline $\begin{array}{l}\text { Biederman et al. } \\
(1992)\end{array}$ & 0.26 & $\begin{array}{l}\text { Further evidence for family-genetic risk factors in attention deficit } \\
\text { hyperactivity disorder: Patterns of comorbidity in probands and relatives in } \\
\text { psychiatrically and pediatric ally referred samples. }\end{array}$ & Yes \\
\hline $\begin{array}{l}\text { American Psychiatric } \\
\text { Association (1987) }\end{array}$ & 0.25 & $\begin{array}{l}\text { Committee on nomenclature and statistics. Diagnostic and Statistical } \\
\text { Manual of Mental Disorders, Revised Third Edition. }\end{array}$ & Yes \\
\hline Bird et al. (1988) & 0.19 & $\begin{array}{l}\text { Estimates of the prevalence of childhood maladjustment in a community } \\
\text { survey in Puerto Rico: The use of combined measures }\end{array}$ & Yes \\
\hline Barkley et al. (1990) & 0.17 & $\begin{array}{l}\text { The adolescent outcome of hyperactive children diagnosed by research } \\
\text { criteria: I. An 8-year prospective follow-up study }\end{array}$ & Yes \\
\hline Lewinsohn et al. (1993) & 0.13 & $\begin{array}{l}\text { Adolescent psychopathology: I. Prevalence and incidence of depression } \\
\text { and other DSM-III_-R disorders in high school students }\end{array}$ & Yes \\
\hline $\begin{array}{l}\text { Schwab-Stone et al., } \\
(1994)\end{array}$ & 0.12 & $\begin{array}{l}\text { Reliability of diagnostic reporting for children aged 6-11 years: a test- } \\
\text { retest study of the Diagnostic Interview Schedule for Children-Revised }\end{array}$ & No \\
\hline Bird et al. (1993) & 0.12 & $\begin{array}{l}\text { Patterns of diagnostic comorbidity in a community sample of children } \\
\text { aged } 9 \text { through } 16 \text { years. }\end{array}$ & No \\
\hline Cohen et al. (1993) & 0.11 & $\begin{array}{l}\text { An epidemiological study of disorders in late childhood and } \\
\text { adolescence-I. Age-and gender-specific prevalence }\end{array}$ & Yes \\
\hline $\begin{array}{l}\text { American Psychiatric } \\
\text { Association (1994) }\end{array}$ & 0.1 & Diagnostic and statistical manual of mental disorders (DSM) & No \\
\hline Pynoos et al. (1987) & 0.1 & Life threat and posttraumatic stress in school age children. & No \\
\hline Lahey et al. (1994) & 0.1 & $\begin{array}{l}\text { DSM-IV field trials for oppositional defiant disorder and conduct disorder } \\
\text { in children and adolescents }\end{array}$ & Yes \\
\hline
\end{tabular}




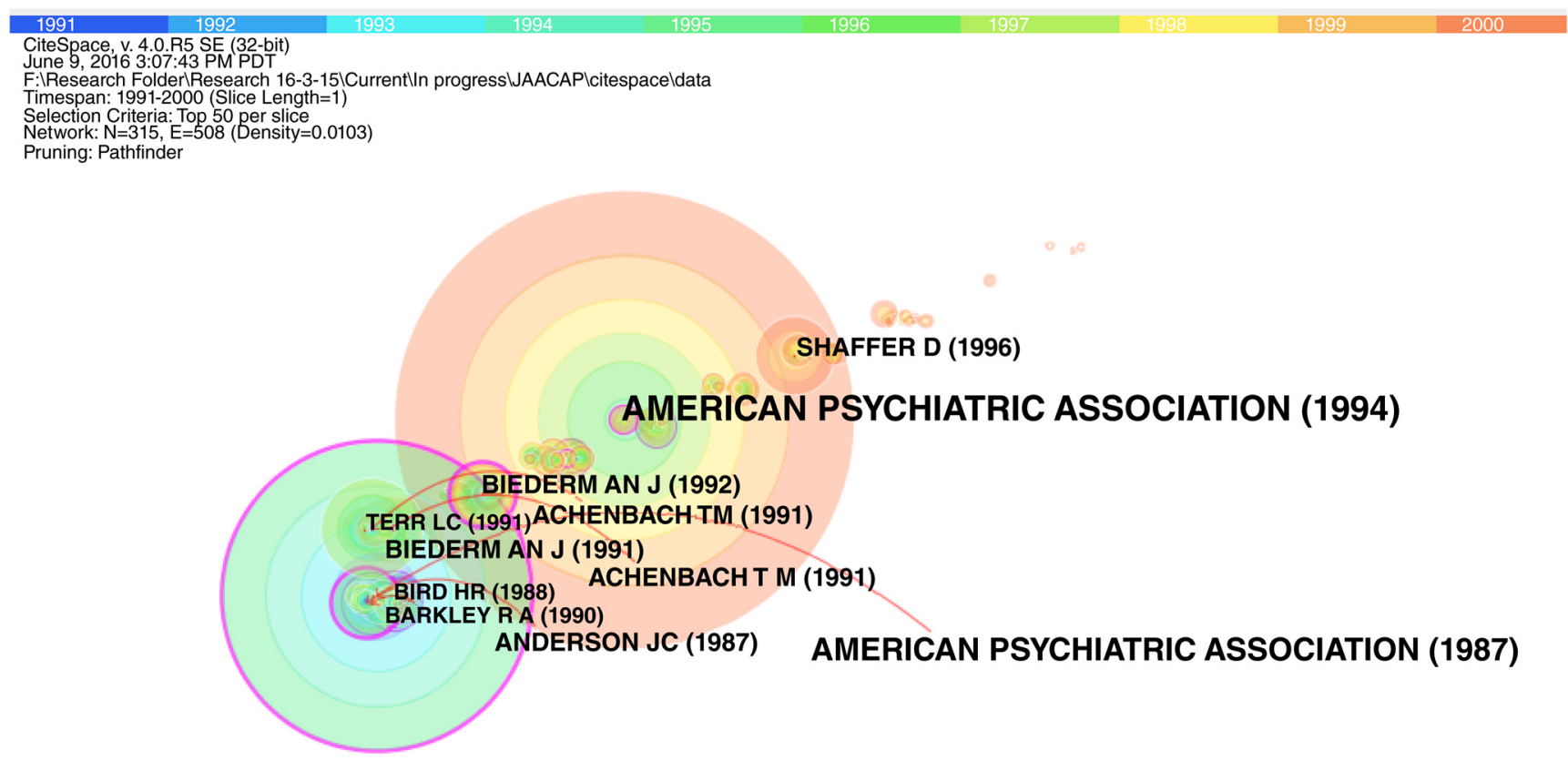

Figure 5. Visualization of important nodes from 1991-2000. Figure 5 represents a visual co-citation network of 315 research documents published in the field of child psychiatry from 1991-2000. The rings represent several key results such as new theories/concepts related to a field (visualized as a purple ring), centrality reflecting the status of a publication in their network/field, and citation tree rings representing year-wise citation pattern of an article.

Although DSM-III was published in 1980, it did not appear as an influential entity in child psychiatry during 1980s. However, it attracted a lot epidemiological studies from 1990-2000, mainly because it operationalized the diagnostic criteria of mental illnesses and used a phenomenological approach. Bird et al. (1993) in his epidemiologic study identified patterns of the comorbidity of four major diagnostic domains (attention deficit disorders, conduct/oppositional disorders, depression and anxiety disorders) among children ${ }^{32}$, and Cohen et al. (1993) reported that patterns of diagnoses varied by both age and gender ${ }^{33}$. Subsequent publications include Anderson et al.'s work investigating the prevalence of DSM-III disorders in preadolescent children ${ }^{34}$, where it was found that the most prevalent disorders were attention deficit, oppositional and separation anxiety disorders. And the least prevalent were depression and social phobia. Bird et al. delineated the demographic correlates of maladjustments and its DSM-III diagnostic domains ${ }^{35}$.

The publication of a DSM III- revised version by the American Psychiatric Association was significant in their own collaborative network, as well as visualized as a purple node representing a landmark work in the field of child psychiaty ${ }^{36}$. Using DSM III- R critera, Lewinsohn et al. identified the prevalence and incidence of depression $^{37}$ and other DSM-III-R disorders among high school students. This decade also included the development of Diagnostic Interview Schedule for Children-Revised (DISC-R), to be used among children, by Schwab-Stone et al. ${ }^{38}$. This was a very important development, as it could be administered by clinicians as well as lay interviewers with no formal clinical training ${ }^{38}$.
The decade also included DSM- IV publication by American Psychiatric Association as an important publication ${ }^{39}$. A study by Lahey et al. compared the psychometric properties of DSM- IV criteria for oppositional defiant disorder and conduct disorder with previous DSM diagnostic formulations ${ }^{40}$. It concluded that DSM-IV definitions and validity of oppositional defiant disorder and conduct disorder are somewhat better than DSM-III-R definitions.

The introduction of cutting edge techniques in child psychiatry integrated new disciplines such as genetics. In 1992, Biederman et al. provided the evidence for family-genetic influences in the development of $\mathrm{ADHD}^{41}$. Table 5 provides a detailed analysis of the articles selected based on their centrality values. Please, note that some of these articles were published in the previous decade but they influenced other research in this decade.

\section{Publications from 2001 to 2010}

There were 306 nodes and 483 edges (Table 5, Figure 6). An eminent scientist in the field of child psychiatry, Angold et al. (1999) conducted a meta-analysis to provide an understanding of comorbidity of different psychiatric disorders ${ }^{42}$. Angold et al. Also highlighted that severity of symptomatology among children and the resulting impairment contributed significantly to parents' burden ${ }^{43}$. Costello et al. conducted a 10 year review update to track the recent progress in child and adolescent psychiatric epidemiology ${ }^{44}$. It summarized the burden and available methods to screen and diagnose mental illnesses among the youth ${ }^{44}$. Similarly, Ford et al. identified the prevalence of DSM-IV disorders by conducting the child and adolescent mental health survey ${ }^{45}$. 
Table 5. Top articles with centrality values $\geq 0.1$ or purple rings (2001-2010).

\begin{tabular}{|c|c|c|c|}
\hline Reference & $\begin{array}{l}\text { Centrality } \\
\text { value }\end{array}$ & Basic theme & $\begin{array}{l}\text { Purple } \\
\text { node }\end{array}$ \\
\hline March et al. (2004) & 0.26 & $\begin{array}{l}\text { Treatment for Adolescents With Depression Study (TADS) Team: Fluoxetine, } \\
\text { cognitive-behavioral therapy, and their combination for adolescents with } \\
\text { depression: Treatment for Adolescents With Depression Study (TADS) } \\
\text { randomized controlled trial }\end{array}$ & Yes \\
\hline $\begin{array}{l}\text { Shaffer et al. } \\
(2000)\end{array}$ & 0.24 & $\begin{array}{l}\text { NIMH Diagnostic Interview Schedule for Children Version IV (NIMH DISC- } \\
\text { IV): description, differences from previous versions, and reliability of some } \\
\text { common diagnoses. }\end{array}$ & Yes \\
\hline $\begin{array}{l}\text { Kim-Cohen et al. } \\
\text { (2003) }\end{array}$ & 0.18 & $\begin{array}{l}\text { Prior juvenile diagnoses in adults with mental disorder: developmental follow- } \\
\text { back of a prospective-longitudinal cohort. }\end{array}$ & Yes \\
\hline $\begin{array}{l}\text { Angold et al. } \\
\text { (1998) }\end{array}$ & 0.18 & $\begin{array}{l}\text { Perceived parental burden and service use for child and adolescent } \\
\text { psychiatric disorders }\end{array}$ & Yes \\
\hline Ford et al. (2003) & 0.17 & The British child and adolescent mental health survey & Yes \\
\hline $\begin{array}{l}\text { Shaffer et al. } \\
\text { (1996) }\end{array}$ & 0.16 & $\begin{array}{l}\text { The NIMH Diagnostic Interview Schedule for Children Version } 2.3 \text { (DISC-2.3): } \\
\text { Description, acceptability, prevalence rates, and performance in the MECA } \\
\text { study. }\end{array}$ & Yes \\
\hline $\begin{array}{l}\text { Faraone et al. } \\
\text { (2005) }\end{array}$ & 0.16 & Molecular genetics of attention-deficit/hyperactivity disorder & Yes \\
\hline $\begin{array}{l}\text { Angold et al. } \\
\text { (1999) }\end{array}$ & 0.15 & Comorbidity & \\
\hline $\begin{array}{l}\text { Castellanos et al. } \\
\text { (2002) }\end{array}$ & 0.15 & $\begin{array}{l}\text { Developmental trajectories of brain volume abnormalities in children and } \\
\text { adolescents with attention-deficit/hyperactivity disorder }\end{array}$ & Yes \\
\hline $\begin{array}{l}\text { Leibenluft et al. } \\
\text { (2003) }\end{array}$ & 0.14 & Defining clinical phenotypes of juvenile mania. & Yes \\
\hline $\begin{array}{l}\text { Costello et al. } \\
\text { (1996) }\end{array}$ & 0.14 & $\begin{array}{l}\text { The Great Smoky Mountains Study of Youth: goals, design, methods, and the } \\
\text { prevalence of DSM-III-R disorders }\end{array}$ & Yes \\
\hline $\begin{array}{l}\text { Gottesman et al. } \\
(2003)\end{array}$ & 0.13 & $\begin{array}{l}\text { The endophenotype concept in psychiatry: etymology and strategic } \\
\text { intentions. }\end{array}$ & Yes \\
\hline $\begin{array}{l}\text { MTA Cooperative } \\
\text { Group (1999) }\end{array}$ & 0.12 & $\begin{array}{l}\text { A 14-month randomized clinical trial of treatment strategies for attention- } \\
\text { deficit/hyperactivity disorder }\end{array}$ & Yes \\
\hline Conners (1997) & 0.12 & Conners' Rating Scales--revised: User's Manual & Yes \\
\hline $\begin{array}{l}\text { American } \\
\text { Psychiatric } \\
\text { Association (2000) }\end{array}$ & 0.11 & Diagnostic criteria from DSM-IV-tr & Yes \\
\hline $\begin{array}{l}\text { Goodman et al. } \\
\text { (2000) }\end{array}$ & 0.11 & $\begin{array}{l}\text { Using the Strengths and Difficulties Questionnaire (SDQ) to screen for child } \\
\text { psychiatric disorders in a community sample. }\end{array}$ & No \\
\hline $\begin{array}{l}\text { Costello et al. } \\
\text { (2005) }\end{array}$ & 0.11 & $\begin{array}{l}\text { 10-year research update review: the epidemiology of child and adolescent } \\
\text { psychiatric disorders: I. Methods and public health burden }\end{array}$ & Yes \\
\hline $\begin{array}{l}\text { Walkup et al. } \\
\text { (2001) }\end{array}$ & 0.1 & $\begin{array}{l}\text { Fluvoxamine for the treatment of anxiety disorders in children and } \\
\text { adolescents. }\end{array}$ & Yes \\
\hline $\begin{array}{l}\text { MTA Cooperative } \\
\text { Group (1999) }\end{array}$ & 0.1 & $\begin{array}{l}\text { Moderators and mediators of treatment response for children with attention- } \\
\text { deficit/hyperactivity disorder: the Multimodal Treatment Study of children with } \\
\text { Attention-deficit/hyperactivity disorder }\end{array}$ & Yes \\
\hline Pine et al. (1998) & 0.1 & $\begin{array}{l}\text { The risk for early-adulthood anxiety and depressive disorders in } \\
\text { adolescents with anxiety and depressive disorders }\end{array}$ & Yes \\
\hline
\end{tabular}




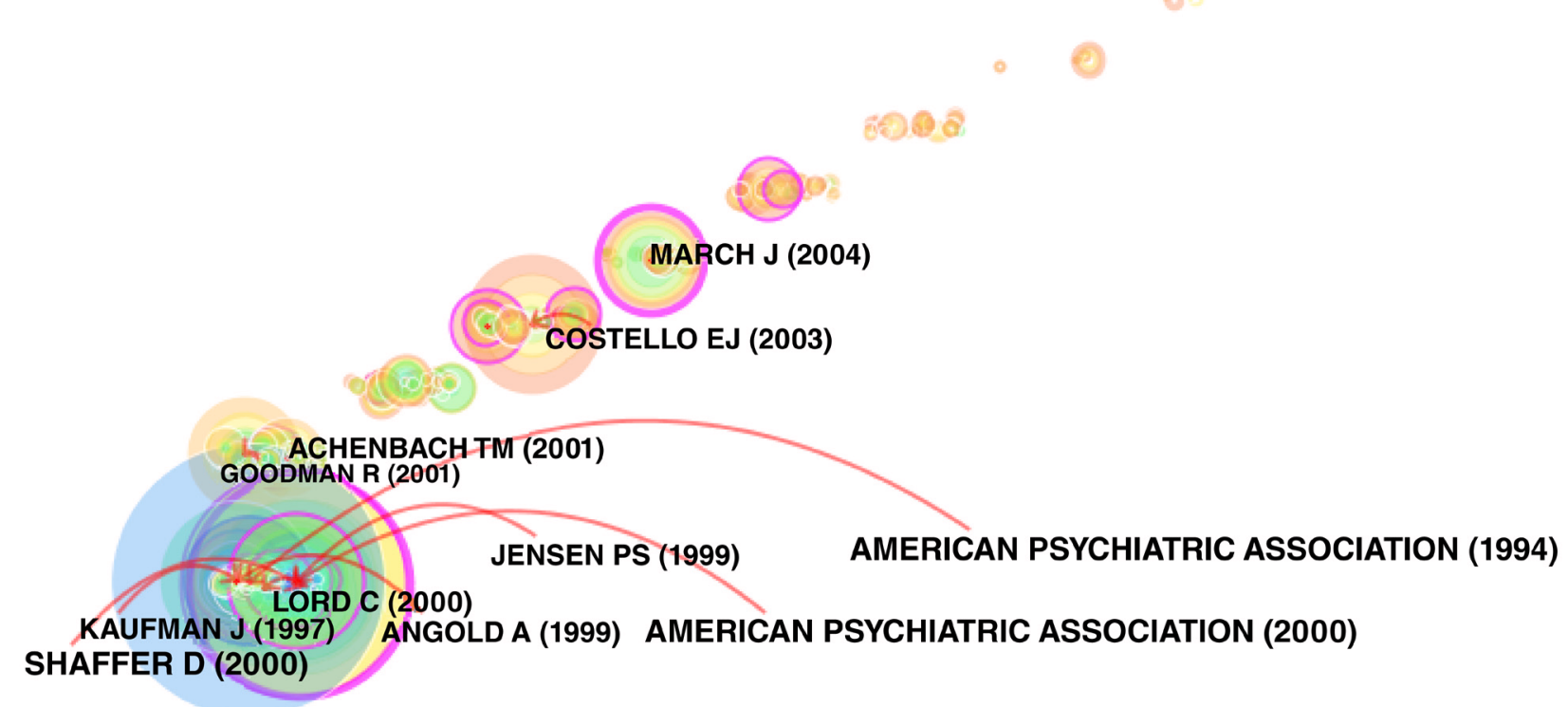

Figure 6. Visualization of important nodes from 2001-2010. Figure 6 represents a visual co-citation network of 306 research documents published in the field of child psychiatry from 2001-2010. The rings represent several key results such as new theories/concepts related to a field (visualized as a purple ring), centrality reflecting the status of a publication in their network/field, and citation tree rings representing year-wise citation pattern of an article.

This decade experienced an influence from a number of landmark prospective cohort studies. Prospective cohort studies provide strong evidence regarding temporality and causality, and minimize recall bias. The studies revolutionized the understanding of the developmental course of psychopathologies. Kim-Cohen et al.'s work (2003) emphasized the public health importance of juvenile disorders by concluding that most adult disorders might be an extension of juvenile disorders ${ }^{46}$. Pine et al. identified anxiety and depressive disorders in adolescence to be a strong risk factor for early-adulthood anxiety and depressive disorders ${ }^{47}$. Costello et al. (1996) influenced this era by their renowned "The Great Smoky Mountain study", which looked at the prevalence of psychiatric disorders in urban and rural population ${ }^{48}$. The study identified several key findings, such as a high burden of psychiatric illnesses among rural populations, externalizing and internalizing dimensions of psychopathologies, and poverty and puberty as a risk factor for depression ${ }^{48}$.

In 2000, the American Psychiatric Association published the DSMIV-TR $^{49}$. Similar to its previous versions, DSM-IV-TR brought about landmark changes (visualized as a purple node) in the field of child psychiatry

In this decade, a particular emphasis was also observed in the study of genetic -environment interaction in development and progression of diseases. These studies stimulated a great deal of research in the domain of psychiatric genetics especially in ADHD and mania. Castellanos et al. concluded that genetic and/or early environmental influences on brain development in ADHD are fixed, non-progressive, and unrelated to stimulant treatment ${ }^{50}$. Faraone et al. reviewed important genetic variances and its association with $\mathrm{ADHD}^{51}$. Leibenluft et al. described the clinical phenotypes of juvenile mania ${ }^{52}$. Gottesman and Gould's work emphasized the importance of endo-phenotypes in the understanding of neurobiological correlates of psychiatric disorders ${ }^{53}$

Similar to previous decades, the work in this period also focused on the importance of assessment, diagnoses and taxonomy of childhood psychiatric disorders. Two scales in particular provided a strong base for screening, diagnoses and research pertaining to ADHD. The Conners' Rating Scales-Revised User Manual published in 1997 garnered a lot of attention in this decade ${ }^{54}$. The scale represents validated instrument with excellent psychometric properties for evaluation, diagnosis, and treatment response of children with ADHD and co-morbid disorders ${ }^{54}$. Goodman et al. employed the Strengths and Difficulties Questionnaire (SDQ) to screen child psychiatric disorders in a community sample ${ }^{55}$. Owing to their inexpensive use by non-trained individuals, these scales are extensively used in screening ADHD among children in school settings, community settings as well as research. 
Providing an updated version of DISC-R, Shaffer et al assessed the reliability of NIMH Diagnostic Interview Schedule for Children Version 2.3 (DISC-2.3) in the MECA study ${ }^{56}$. Subsequent papers included Shaffer et al.'s comparison of NIMH Diagnostic Interview Schedule for Children Version IV (NIMH DISC-IV) with its previous versions, and its reliability for some common diagnoses ${ }^{57}$.

In this decade, a lot of pharmacological research was guided by several influential studies on depression, anxiety and ADHD among children. The most important paper with a centrality value of 0.26 and identified as a purple node was titled "Treatment for adolescents with depression Study (TADS) Team: Fluoxetine, cognitive-behavioral therapy, and their combination for adolescents with depression" by March et al. ${ }^{58}$. This study concluded that the combination of CBT and SSRI is the most efficacious for treating major depression among adolescent population. It also helped guide the National Institute for Health and Clinical Excellence (NICE) guidelines for treating adolescent depression.

Another trial proved that fluvoxamine is efficacious in childhood and adolescent anxiety disorders ${ }^{59}$. The MTA Cooperative Group tested the treatment strategies for $\mathrm{ADHD}^{60}$ and also identified the moderators and mediators of treatment response for children with $\mathrm{ADHD}^{61}$. This was one of the most influential study guiding future research on treatment of ADHD. Since 1999, when the NIMH study was published, thousands of additional peer-reviewed studies have been published on the topic of ADHD treatment.

\section{Publications from 2011 to 2016}

There were 209 nodes and 313 edges (Table 6, Figure 7). "The fifth edition of Diagnostic and statistical manual of mental disorders (DSM-5)" was identified as the most important publication. ${ }^{62}$.

Table 6. Top articles with centrality values $\geq 0.1$ or purple rings (2011-2016).

\begin{tabular}{|c|c|c|c|}
\hline Reference & $\begin{array}{l}\text { Centrality } \\
\text { value }\end{array}$ & Basic theme & $\begin{array}{l}\text { Purple } \\
\text { node }\end{array}$ \\
\hline $\begin{array}{l}\text { American Psychiatric } \\
\text { Association (2013) }\end{array}$ & 0.35 & Diagnostic and statistical manual of mental disorders (DSM-5) & Yes \\
\hline Leibenluft (2011) & 0.31 & $\begin{array}{l}\text { Severe mood dysregulation, irritability, and the diagnostic boundaries of } \\
\text { bipolar disorder in youths. }\end{array}$ & Yes \\
\hline $\begin{array}{l}\text { Polanczyk et al. } \\
\text { (2007) }\end{array}$ & 0.27 & $\begin{array}{l}\text { The worldwide prevalence of ADHD: a systematic review and meta- } \\
\text { regression analysis. }\end{array}$ & Yes \\
\hline Althoff et al. (2010) & 0.24 & Adult outcomes of childhood dysregulation: a 14-year follow-up study. & Yes \\
\hline $\begin{array}{l}\text { Stringaris and } \\
\text { Goodman (2009) }\end{array}$ & 0.22 & $\begin{array}{l}\text { Longitudinal outcome of youth oppositionality: irritable, headstrong, and } \\
\text { hurtful behaviors have distinctive predictions }\end{array}$ & Yes \\
\hline $\begin{array}{l}\text { Sonuga-Barke et al. } \\
(2013)\end{array}$ & 0.2 & $\begin{array}{l}\text { Nonpharmacological interventions for ADHD: systematic review } \\
\text { and meta-analyses of randomized controlled trials of dietary and } \\
\text { psychological treatments. }\end{array}$ & Yes \\
\hline Nylund et al. (2007) & 0.16 & $\begin{array}{l}\text { Deciding on the number of classes in latent class analysis and growth } \\
\text { mixture modeling: A Monte Carlo simulation study }\end{array}$ & Yes \\
\hline Birmaher et al. (2007) & 0.16 & $\begin{array}{l}\text { Practice parameter for the assessment and treatment of children and } \\
\text { adolescents with depressive disorders. }\end{array}$ & Yes \\
\hline $\begin{array}{l}\text { Egger and Angold } \\
(2006)\end{array}$ & 0.15 & $\begin{array}{l}\text { Common emotional and behavioral disorders in preschool children: } \\
\text { presentation, nosology, and epidemiology }\end{array}$ & Yes \\
\hline $\begin{array}{l}\text { Frick and White } \\
\text { (2008) }\end{array}$ & 0.13 & $\begin{array}{l}\text { Research review: The importance of callous-unemotional traits for } \\
\text { developmental models of aggressive and antisocial behavior. }\end{array}$ & Yes \\
\hline Simonoff et al. (2008) & 0.13 & $\begin{array}{l}\text { Psychiatric disorders in children with autism spectrum disorders: } \\
\text { prevalence, comorbidity, and associated factors in a population-derived } \\
\text { sample. }\end{array}$ & Yes \\
\hline Walkup et al. (2008) & 0.13 & $\begin{array}{l}\text { Cognitive behavioral therapy, sertraline, or a combination in childhood } \\
\text { anxiety }\end{array}$ & Yes \\
\hline $\begin{array}{l}\text { Copeland et al. } \\
\text { (2009) }\end{array}$ & 0.13 & $\begin{array}{l}\text { Childhood and adolescent psychiatric disorders as predictors of young } \\
\text { adult disorders. }\end{array}$ & Yes \\
\hline Kessler et al. (2005) & 0.12 & $\begin{array}{l}\text { Lifetime prevalence and age-of-onset distributions of DSM-IV disorders } \\
\text { in the National Comorbidity Survey Replication }\end{array}$ & Yes \\
\hline $\begin{array}{l}\text { Silverman et al. } \\
(2008)\end{array}$ & 0.12 & $\begin{array}{l}\text { Evidence-based psychosocial treatments for phobic and anxiety } \\
\text { disorders in children and adolescents. }\end{array}$ & Yes \\
\hline Wolke et al. (2009) & 0.11 & $\begin{array}{l}\text { Selective drop-out in longitudinal studies and non-biased prediction of } \\
\text { behaviour disorders. }\end{array}$ & Yes \\
\hline Willcutt et al. (2012) & 0.11 & $\begin{array}{l}\text { Validity of DSM-IV attention deficit/hyperactivity disorder symptom } \\
\text { dimensions and subtypes. }\end{array}$ & Yes \\
\hline $\begin{array}{l}\text { Stringaris and } \\
\text { Goodman (2009) }\end{array}$ & 0.1 & Three dimensions of oppositionality in youth & Yes \\
\hline
\end{tabular}




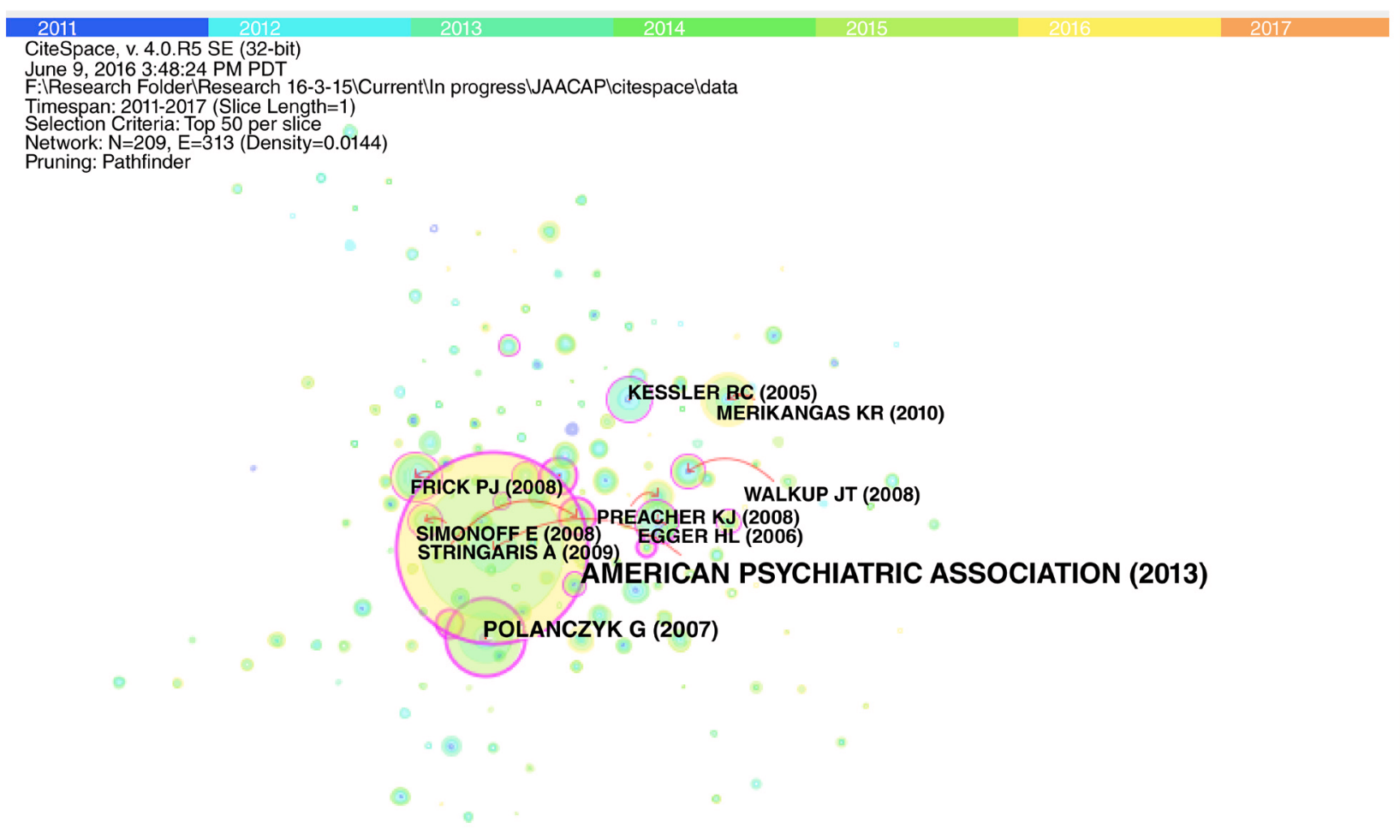

Figure 7. Visualization of important nodes from 2011- July 2016. Figure 7 represents a visual co-citation network of 209 research documents published in the field of child psychiatry from 2011-2016. The rings represent several key results such as new theories/concepts related to a field (visualized as a purple ring), centrality reflecting the status of a publication in their network/field, and citation tree rings representing year-wise citation pattern of an article.

Willcutt et al $^{63}$ reviewed the validity of DSM-IV attention deficit/hyperactivity disorder symptom dimensions and subtypes. Our analysis identified two important works in epidemiology; elucidating the prevalence of childhood psychiatric disorders. In his metaanalysis, Polanczyk analyzed the causes for worldwide variation in estimates of $\mathrm{ADHD}^{64}$. Kessler et al. ${ }^{65}$ conducted a survey to estimate the lifetime prevalence and age of onset of distributions of DSM-IV disorders in the National Comorbidity Survey Replication.

This decade also attracted a lot of research on disruptive disorders among children. Stringaris \& Goodman ${ }^{66}$ recognized three dimensions of oppositionality in youth; irritability, hurtful and headstrong, deeming them as differential predictors of aetiology, prognosis and treatment responsiveness. Later, Stringaris \& Goodman assessed the longitudinal outcomes of these three dimensions, with irritability predicting depression and anxiety, headstrong dimension with ADHD and hurtful dimension predicting aggressive conduct disorder ${ }^{67}$. White ${ }^{68}$ reviewed the importance of callous traits for developmental models of aggressive and antisocial behavior and Wolke et al. ${ }^{69}$ investigated whether drop out in the Avon Longitudinal Study of Parents And Children (ALSPAC) is systemic or random and if systematic, whether it had an impact on the prediction of disruptive behavior disorders.
Egger \& Angold (2006) conducted an important review about common emotional and behavioral disorders in preschool children ${ }^{70}$. Subsequent papers include Leibenluft's work on severe mood dysregulation, irritability, and the diagnostic boundaries of bipolar disorder in youth ${ }^{71}$. It emphasized that severe mood dysregulation disorder is a different diagnostic entity than Bipolar Disorder, while Frick and Simonoff et al. ${ }^{72}$ elucidated that social anxiety disorders, ADHD and conduct disorders were most comorbid with autism spectrum disorders.

Two prospective studies influenced research in this decade. These included Althoff et al's 14-year follow-up study, concluding childhood dysregulation identified using the child behavior checklist-dysregulation profile (CBCL-DP) could predict anxiety and behavior disruptive disorders in adulthood ${ }^{73}$. Copeland et al ${ }^{74}$ identified childhood and adolescent psychiatric disorders as predictors of young adult disorders.

Walkup et al. ${ }^{75}$ published a randomized controlled trial to assess treatment options of childhood anxiety disorders. They concluded that a combination of cognitive behavioral therapy and Sertraline to be of greatest efficacy in childhood anxiety. And Birmaher \& Brent identified practice parameters for the assessment and treatment of 
children and adolescents with depressive disorders ${ }^{76}$. This decade also included two influential studies on non-pharmacological interventions. In contrast to previous studies that had focused on pharmacological treatments for ADHD, Sonuga-Barke et al. reviewed the evidence for non-pharmacological interventions ${ }^{77}$ such as Free fatty acid supplementation, artificial food color exclusion, behavioral interventions, neurofeedback, cognitive training, and restricted elimination. Similarly, Silverman et $a l .^{78}$ reviewed the evidencebased psychosocial treatments for phobic and anxiety disorders in children and adolescents.

This decade was also particularly influenced by Nylund and colleagues' work on latent class analysis and mixture modeling techniques, commonly used in behavioral and social science research for identifying patterns of behaviors, psychiatric symptoms and disorders, and co-occurrence of aspects of the social environment ${ }^{79}$.

\section{Dataset 1 . Source data utilized in this study, compiled into text documents}

http://dx.doi.org/10.5256/f1000research.12069.d170670

The data is also accessible via the Clarivate analytics Web of Science Core database.

\section{Discussion}

The field of child psychiatry is still a relatively new and expanding field, in comparison to other specialties of medicine. It has evolved significantly over the last few years. Most of the literature in this field was contributed by United States of America and the European countries, with small contributions from the developing countries. Similar trends were observed in the regional distribution of funding agencies and authors contributing to this field. Several pharmaceutical industries were also identified among top ten funding agencies. A number of landmark papers and research foci were also identified. During the first three decades, the researchers focused on assessment tools, taxonomy, identification of risk factors, and symptomatology. Over time, there has been a growing interest in finding better assessment tools and more effective psychopharmacological options. However, more recently, there has been a rapid development in several areas including neurobiology, neuroimaging, and molecular genetics. Researchers are more interested in exploring etiological factors leading to psychiatric illnesses. The authors strongly believe that these innovative trends in the field would help identify and manage the childhood psychiatric disorders at an earlier stage, and also increase the quality of life among patients, their families and caretakers.

\section{Data availability}

Dataset 1: Source data utilized in this study, compiled into text documents. The data is also accessible via the Clarivate analytics Web of Science Core database. DOI, 10.5256/f1000research.12069. d170670 80

\section{Competing interests}

No competing interests were disclosed.

\section{Grant information}

The author(s) declared that no grants were involved in supporting this work.

\section{Acknowledgements}

The authors thank Dr. Hamid Hassan, Assistant Professor of Applied Physiology, Multan Medical and Dental College, Pakistan, for improving the use of English in this manuscript. The authors also thank Professor Chaomei Chen, Professor of Informatics in the College of Computing and Informatics at Drexel University, for providing his valuable comments to improve the paper.
1. O'Connell M, Boat T, Warner K: Preventing mental, emotional, and behavioral disorders among young people: Progress and possibilities. 2009. Reference Source

2. Rey JM, Assumpção FB Jr, Bernad CA, et al:: HISTORY OF CHILD PSYCHIATRY. 2015.

Reference Source

3. Bewley T: Development of specialties - Child psychiatry. (Madness to Mental Illness. A History of the Royal College of Psychiatrists.). 1-11. Reference Source

4. McCord J, Spatz Wisdom C, Crowell N: Juvenile Crime, Juvenile Justice. Panel on Juvenile Crime: Prevention, Treatment, and Control. National Research Council and Institute of Medicine, Committee on Law and Justice and Board on Children, Youth, and Families.; 2001. Reference Source

5. Stewart J: US Influences on the Development of Child Guidance and Psychiatric Social Work in Scotland and Great Britain during the Interwar Period. In: Andresen A, Elybakken KT, Hubbard W, editors. Public Health and Preventive Medicine, 1800-2000: Knowledge, Co-operation, and Conflict. Bergen, Stein Rokkan Centre for Social Studies; 2000; 85-95.
6. Schowalter J: A history of child and adolescent psychiatry in the United States. Psychiatr Times. 2003.

Reference Source

7. Albayrak O, Föcker M, Wibker K, et al.: Bibliometric assessment of publication output of child and adolescent psychiatric/psychological affiliations between 2005 and 2010 based on the databases PubMed and Scopus. European child \& adolescent psychiatry. Eur Child Adolesc Psychiatry. 2012; 21(6): 327-37. PubMed Abstract | Publisher Full Text

8. Hess D: Science Studies: An advanced introduction. New York: New York University Press; 1997 Reference Source

9. Wu Y, Duan Z: Analysis on evolution and research focus in psychiatry field. BMC Psychiatry. 2015; 15(1): 105.

PubMed Abstract | Publisher Full Text | Free Full Text

10. $\mathrm{Wu} Y$, Duan $Z$ : Visualization analysis of author collaborations in schizophrenia research. BMC Psychiatry. 2015; 15(1): 27. PubMed Abstract | Publisher Full Text | Free Full Text

11. Knutas A, Hajikhani A, Salminen J, et al:: Cloud-based bibliometric analysis service for systematic mapping studies. Proc 16th Int Conf Comput Syst Technol. 
2015; 184-91

Publisher Full Text

12. Chen C, Sanjuan Fl, Hou J: The Structure and Dynamics of Co-Citation Clusters: A Multiple Perspective Co-Citation Analysis. J Am Soc Inf Sci Technol. 2010; 61(7): 1386-409.

Publisher Full Text

13. Small H: Co-citation in the scientific literature: A new measure of the relationship between two documents. J Am Soc Inf. 1973; 24(4): 265-9. Publisher Full Text

14. Marshakova I: System of connections between documents based on references (as the Science Citation Index). Nauchno-Tekhnicheskaya Informatsiya Seriya. 1973; 2(6): 3-8.

15. Liu Z, Chen Y, Ying L, et al.: Mapping knowledge domains methods and application. Beijing: People's Publishing House; 2008.

Reference Source

16. ISI Thompson Reuters. Master Journal List. Reference Source

17. Polanczyk GV, Salum GA, Sugaya LS, et al:: Annual Research Review: A metaanalysis of the worldwide prevalence of mental disorders in children and adolescents. J Child Psychol Psychiatry. 2015; 56(3): 345-65. PubMed Abstract | Publisher Full Text

18. López-Muñoz F, Alamo C, Quintero-Gutiérrez FJ, et al.: A bibliometric study of international scientific productivity in attention-deficit hyperactivity disorder covering the period 1980-2005. Eur Child Adolesc Psychiatry. 2008; 17(6): 381-91. PubMed Abstract | Publisher Full Text

19. Carlson GA, Cantwell DP: Unmasking masked depression in children and adolescents. Am J Psychiatry. 1980; 137(4): 445-9.

PubMed Abstract | Publisher Full Text

20. Cantwell DP: Hyperactivity and Antisocial Behavior. J Am Acad Child Psychiatry 1978; 17(2): 252-62.

PubMed Abstract | Publisher Full Text

21. Lewis DO, Shanok SS, Pincus JH, et al.: Violent juvenile delinquents: psychiatric, neurological, psychological, and abuse factors. J Am Acad Child Psychiatry. 1979; 18(2): 307-19.

PubMed Abstract | Publisher Full Text

22. Rey JM, Jr FBA, Bernad CA, et al:: Chapter. 2015; 1-72.

23. Shaffer D, Gould MS, Brasic J, et al.: A children's global assessment scale (CGAS). Arch Gen Psychiatry. 1983; 40(11): 1228-31.

PubMed Abstract | Publisher Full Text

24. Achenbach T: DSM-III in light of empirical research on the classification of child psychopathology. J Am Acad Child Psychiatry. 1980; 19(3): 395-412. PubMed Abstract | Publisher Full Text

25. Achenbach T: Manual for the child behavior checklist and revised child behavior profile. Department of Psychiatry of the University of Vermont; 1983. Reference Source

26. Ainsworth M, Blehar M, Waters E, et al:: Patterns of attachment: A psychological study of the strange situation. Hillsdale. NJ: Erlbaum; 1978. Reference Source

27. Egeland B, Sroufe LA: Attachment and early maltreatment. Child Dev. 1981 52(1): 44-52.

PubMed Abstract | Publisher Full Text

28. Gaensbauer TJ, Sands K: Distorted affective communications in abused/ neglected infants and their potential impact on caretakers. J Am Acad Child Psychiatry. 1979; 18(2): 236-50.

PubMed Abstract | Publisher Full Text

29. Brent DA, Perper JA, Goldstein CE, et al:: Risk factors for adolescent suicide. a comparison of adolescent suicide victims with suicidal inpatients. Arch Gen Psychiatry. 1988; 45(6): 581-8.

PubMed Abstract | Publisher Full Text

30. Pynoos RS, Frederick $\mathrm{C}$, Nader K, et al.: Life threat and posttraumatic stress in school-age children. Arch Gen Psychiatry. 1987; 44(12): 1057-63. PubMed Abstract | Publisher Full Text

31. Barkley RA, Fischer M, Edelbrock CS, et al:: The adolescent outcome of hyperactive children diagnosed by research criteria: I. An 8-year prospective follow-up study. J Am Acad Child Adolesc Psychiatry. 1990; 29(4): 546-557. PubMed Abstract | Publisher Full Text

32. Bird HR, Gould MS, Staghezza BM: Patterns of diagnostic comorbidity in a community sample of children aged 9 through 16 years. J Am Acad Child Adolesc Psychiatry. 1993; 32(2): 361-8. PubMed Abstract | Publisher Full Text

33. Cohen $\mathrm{P}$, Cohen J, Kasen S, et al:: An epidemiological study of disorders in lat childhood and adolescence--I. Age- and gender-specific prevalence. J Child Psychol Psychiatry. 1993; 34(6): 851-67. PubMed Abstract | Publisher Full Text

34. Anderson JC, Williams S, Mcgee R, et al:: DSM-III disorders in preadolescent children. Prevalence in a large sample from the general population. Arch Gen Psychiatry. 1987; 44(1): 69-76. PubMed Abstract | Publisher Full Text

35. Bird HR, Canino G, Rubio-Stipec M, et al:: Estimates of the prevalence of childhood maladjustment in a community survey in Puerto Rico. The use of combined measures. Arch Gen Psychiatry. 1988; 45(12): 1120-6. PubMed Abstract | Publisher Full Text
36. American Psychiatric Association: Committee on nomenclature and statistics. Diagnostic and Statistical Manual of Mental Disorders, Revised Third Edition. American Psychiatric Association; 1987.

37. Lewinsohn PM, Hops H, Roberts RE, et al:: Adolescent psychopathology: I. Prevalence and incidence of depression and other DSM-III-R disorders in high school students. J Abnorm Psychol. 1993; 102(1): 133-44.

PubMed Abstract | Publisher Full Text

38. Schwab-Stone M, Fallon $\mathrm{T}$, Briggs $\mathrm{M}$, et al.: Reliability of diagnostic reporting for children aged 6-11 years: a test-retest study of the Diagnostic Interview Schedule for Children-Revised. Am J Psychiatry. 1994; 151(7): 1048-54. PubMed Abstract | Publisher Full Text

39. American Psychiatric Association: Diagnostic and statistical manual of mental disorders (DSM). American Psychiatric Association; 1994; 143-147. Reference Source

40. Lahey BB, Applegate B, Barkley RA, et al:: DSM-IV field trials for oppositional defiant disorder and conduct disorder in children and adolescents. $A m \mathrm{~J}$ Psychiatry. 1994; 151(8): 1163-71. PubMed Abstract | Publisher Full Text

41. Biederman J, Faraone SV, Keenan K, et al.: Further evidence for family-genetic risk factors in attention deficit hyperactivity disorder. Patterns of comorbidity in probands and relatives psychiatrically and pediatrically referred samples. Arch Gen Psychiatry. 1992; 49(9): 728-38.

PubMed Abstract | Publisher Full Text

42. Angold A, Costello EJ, Erkanli A: Comorbidity. J child Psychol psychiatry. 1999; 40(1): 57-87.

PubMed Abstract | Publisher Full Text

43. Angold A, Messer SC, Stangl D, et al.: Perceived parental burden and service use for child and adolescent psychiatric disorders. Am J Public Health. 1998; 88(1): 75-80.

PubMed Abstract | Publisher Full Text | Free Full Text

44. Costello EJ, Egger $\mathrm{H}$, Angold A: 10-year research update review: the epidemiology of child and adolescent psychiatric disorders: I. Methods and public health burden. J Am Acad Child Adolesc Psychiatry. 2005; 44(10): 972-86. PubMed Abstract | Publisher Full Text

45. Ford T, Goodman R, Meltzer H: The British Child and Adolescent Mental Health Survey 1999: the prevalence of DSM-IV disorders. J Am Acad Child Adolesc Psychiatry. 2003; 42(10): 1203-11.

PubMed Abstract | Publisher Full Text

46. Kim-Cohen J, Caspi A, Moffitt TE, et al.: Prior juvenile diagnoses in adults with mental disorder: developmental follow-back of a prospective-longitudinal cohort. Arch Gen Psychiatry. 2003; 60(7): 709-17.

PubMed Abstract | Publisher Full Text

47. Pine DS, Cohen P, Gurley D, et al.: The risk for early-adulthood anxiety and depressive disorders in adolescents with anxiety and depressive disorders. Arch Gen Psychiatry. 1998; 55(1): 56-64.

PubMed Abstract | Publisher Full Text

48. Costello EJ, Angold A, Burns BJ, et al:: The Great Smoky Mountains Study of Youth. goals, design, methods, and the prevalence of DSM-III-R disorders. Arch Gen Psychiatry. 1996; 53(12): 1129-36.

PubMed Abstract | Publisher Full Tex

49. American Psychiatric Association: Diagnostic criteria from dsM-iV-tr. 2000.

50. Castellanos FX, Lee PP, Sharp W, et al.: Developmental trajectories of brain volume abnormalities in children and adolescents with attention-deficit hyperactivity disorder. JAMA. 2002; 288(14): 1740-8.

PubMed Abstract | Publisher Full Text

51. Faraone SV, Perlis RH, Doyle AE, et al:: Molecular genetics of attention-deficit/ hyperactivity disorder. Biol Psychiatry. 2005; 57(11): 1313-23.

PubMed Abstract | Publisher Full Text

52. Leibenluft E, Charney DS, Towbin KE, et al:: Defining clinical phenotypes of juvenile mania. Am J Psychiatry. 2003; 160(3): 430-7.

PubMed Abstract | Publisher Full Text

53. Gottesman II, Gould TD: The endophenotype concept in psychiatry: etymology and strategic intentions. Am J Psychiatry. 2003; 160(4): 636-45. PubMed Abstract | Publisher Full Text

54. Conners CK: Conners' Rating Scales-revised. Multi-Health Systems, Incorporated; 1997.

55. Goodman R, Ford T, Simmons H, et al:: Using the Strengths and Difficulties Questionnaire (SDQ) to screen for child psychiatric disorders in a community sample. Br J Psychiatry. 2000; 177(6): 534-9.

PubMed Abstract | Publisher Full Text

56. Shaffer D, Fisher P, Dulcan MK, et al:: The NIMH Diagnostic Interview Schedule for Children Version 2.3 (DISC-2.3): description, acceptability, prevalence rates, and performance in the MECA Study. Methods for the Epidemiology of Child and Adolescent Mental Disorders Study. J Am Acad Child Adolesc Psychiatry. 1996; 35(7): 865-77.

PubMed Abstract | Publisher Full Text

57. Shaffer D, Fisher P, Lucas CP, et al.: NIMH Diagnostic Interview Schedule for Children Version IV (NIMH DISC-IV): description, differences from previous versions, and reliability of some common diagnoses. J Am Acad Child Adolesc Psychiatry. 2000; 39(1): 28-38.

PubMed Abstract | Publisher Full Text

58. March J, Silva S, Petrycki S, et al:: Fluoxetine, cognitive-behavioral therapy, and their combination for adolescents with depression: Treatment for Adolescents 
With Depression Study (TADS) randomized controlled trial. JAMA. 2004; 292(7): 807-20.

PubMed Abstract | Publisher Full Text

59. Walkup JT, Labellarte MJ, Riddle MA, et al.: Fluvoxamine for the treatment of anxiety disorders in children and adolescents. The Research Unit on Pediatric Psychopharmacology Anxiety Study Group. N Engl J Med. 2001; 344(17): 1279-85.

PubMed Abstract | Publisher Full Text

60. The MTA Cooperative Group: A 14-month randomized clinical trial of treatment strategies for attention-deficit/hyperactivity disorder. The MTA Cooperative Group. Multimodal Treatment Study of Children with ADHD. Arch Gen Psychiatry. 1999; 56(12): 1073-86.

PubMed Abstract | Publisher Full Text

61. The MTA Cooperative Group: Moderators and mediators of treatment response for children with attention-deficit/hyperactivity disorder: the Multimodal Treatment Study of children with Attention-deficit/hyperactivity disorder. Arch Gen Psychiatry. 1999; 56(12): 1088-96.

PubMed Abstract | Publisher Full Text

62. American Psychiatric Association (APA): Diagnostic and statistical manual of mental disorders (DSM-5). 2013.

Reference Source

63. Willcutt EG, Nigg JT, Pennington BF, et al.: Validity of DSM-IV attention deficit/ hyperactivity disorder symptom dimensions and subtypes. $J$ Abnorm Psychol. 2012; 121(4): 991-1010

PubMed Abstract | Publisher Full Text | Free Full Text

64. Polanczyk G, de Lima S, Horta BL: The Worldwide Prevalence of ADHD: A Systematic Review and Metaregression Analysis Reproduced with permission of the copyright owner. Further reproduction prohibited without permission. Am J. 2007; 164(6): 942-8.

Reference Source

65. Kessler RC, Berglund $\mathrm{P}$, Demler $\mathrm{O}$, et al.: Lifetime prevalence and age-ofonset distributions of DSM-IV disorders in the National Comorbidity Survey Replication. Arch Gen Psychiatry. 2005; 62(6): 593-602. PubMed Abstract | Publisher Full Text

66. Stringaris A, Goodman R: Three dimensions of oppositionality in youth. $J$ Child Psychol Psychiatry Allied Discip. 2009; 50(3): 216-23.

PubMed Abstract | Publisher Full Text

67. Stringaris A, Goodman R: Longitudinal outcome of youth oppositionality: irritable, headstrong, and hurtful behaviors have distinctive predictions. $J$ Am Acad Child Adolesc Psychiatry. 2009; 48(4): 404-12.

PubMed Abstract | Publisher Full Text

68. Frick PJ, White SF: Research review: The importance of callous-unemotional traits for developmental models of aggressive and antisocial behavior. $J$ Child Psychol Psychiatry. 2008; 49(4): 359-75.

PubMed Abstract | Publisher Full Text

69. Wolke D, Waylen A, Samara M, et al: Selective drop-out in longitudinal studies and non-biased prediction of behaviour disorders. Br J Psychiatry. 2009; 195(3):
249-56.

PubMed Abstract | Publisher Full Text | Free Full Text

70. Egger $\mathrm{HL}$, Angold A: Common emotional and behavioral disorders in preschool children: presentation, nosology, and epidemiology. J Child Psychol Psychiatry. 2006; 47(3-4): 313-37.

PubMed Abstract | Publisher Full Text

71. Leibenluft E: Severe mood dysregulation, irritability, and the diagnostic boundaries of bipolar disorder in youths. Am J Psychiatry. 2011; 168(2): 129-42.

PubMed Abstract | Publisher Full Text | Free Full Text

72. Simonoff E, Pickles A, Charman T, et al:: Psychiatric disorders in children with autism spectrum disorders: prevalence, comorbidity, and associated factors in a population-derived sample. J Am Acad Child Adolesc Psychiatry. 2008; 47(8): 921-9.

PubMed Abstract | Publisher Full Text

73. Althoff RR, Verhulst FC, Rettew DC, et al:: Adult outcomes of childhood dysregulation: a 14-year follow-up study. J Am Acad Child Adolesc Psychiatry. 2010; 49(11): 1105-16.

PubMled Abstract | Publisher Full Text | Free Full Text

74. Copeland WE, Shanahan L, Costello EJ, et al:: Childhood and adolescent psychiatric disorders as predictors of young adult disorders. Arch Gen Psychiatry. 2009; 66(7): 764-72.

PubMed Abstract | Publisher Full Text | Free Full Text

75. Walkup JT, Albano AM, Piacentini J, et al: Cognitive behavioral therapy, sertraline, or a combination in childhood anxiety. N Engl J Med. 2008; 359(26): 2753-66.

PubMed Abstract | Publisher Full Text | Free Full Text

76. Birmaher B, Brent D, AACAP Work Group on Quality Issues: Practice parameter for the assessment and treatment of children and adolescents with depressive disorders. J Am Acad Child Adolesc Psychiatry. 2007; 46(11): 1503-26. PubMed Abstract | Publisher Full Text

77. Sonuga-Barke EJ, Brandeis D, Coreste S, et al.: Nonpharmacological interventions for ADHD: systematic review and meta-analyses of randomized controlled trials of dietary and psychological treatments. Am J Psychiatry. 2013; 170(3): 275-89.

PubMed Abstract | Publisher Full Text

78. Silverman WK, Pina AA, Viswesvaran C: Evidence-based psychosocial treatments for phobic and anxiety disorders in children and adolescents. $J$ Clin Child Adolesc Psychol. 2008; 37(1): 105-30. PubMed Abstract | Publisher Full Text

79. Nylund KL, Asparouhov T, Muthén BO: Deciding on the number of classes in latent class analysis and growth mixture modeling: A Monte Carlo simulation study. Struct Equ Model. 2007; 14(4): 535-69. Publisher Full Text

80. Naveed S, Waqas A, Majeed S, et al.: Dataset 1 in: Child psychiatry: A scientometric analysis from 1980-2016. F1000Research. 2017. Data Source 


\section{Open Peer Review}

\section{Current Peer Review Status:}

\section{Version 1}

Reviewer Report 01 November 2017

https://doi.org/10.5256/f1000research.13058.r26279

(C) 2017 Mishra D. This is an open access peer review report distributed under the terms of the Creative Commons Attribution License, which permits unrestricted use, distribution, and reproduction in any medium, provided the original work is properly cited.

\section{Deepa Mishra}

DeGroote School of Business, McMaster University, Hamilton, ON, Canada

In this study, authors conducted a bibliometric analysis of articles published from 1980 to 2016, in the top seven journals of child and adolescent psychiatry. The paper is well written but can only be accepted has after these changes. Specifically:

1. In the Abstract Section, Conclusions is just a restatement of the Results Section. I believe the paper has much more to offer than what is mentioned in Conclusions.

2. Discussion section should be rewritten to highlight some future research directions also. This will definitely improve the quality of the paper.

3. For Visualization of important nodes (Figure 4), authors can use other software like Gephi, as the figure is not depicting the results properly. It is very difficult for readers to understand the concept.

Is the work clearly and accurately presented and does it cite the current literature? Yes

Is the study design appropriate and is the work technically sound?

Yes

Are sufficient details of methods and analysis provided to allow replication by others? Yes

If applicable, is the statistical analysis and its interpretation appropriate? Partly

Are all the source data underlying the results available to ensure full reproducibility? Yes

Are the conclusions drawn adequately supported by the results? 
Yes

Competing Interests: No competing interests were disclosed.

I confirm that I have read this submission and believe that I have an appropriate level of expertise to confirm that it is of an acceptable scientific standard.

Reviewer Report 05 September 2017

https://doi.org/10.5256/f1000research.13058.r25167

(C) 2017 Azeem M. This is an open access peer review report distributed under the terms of the Creative Commons Attribution License, which permits unrestricted use, distribution, and reproduction in any medium, provided the original work is properly cited.

\section{Muhammad Waqar Azeem}

Sidra Medical and Research Center, Weill Cornell Medical College in Qatar, Doha, Qatar

Excellent work by authors in reviewing the literature on child and adolescent psychiatry.

Would be important to mention in the limitations that quite a few child and adolescent psychiatry articles are published in journals for paediatrics and general psychiatry.

Secondly Clinics of North America usually publish articles which are usually review of the literature about different issues.

Is the work clearly and accurately presented and does it cite the current literature? Yes

Is the study design appropriate and is the work technically sound?

Yes

Are sufficient details of methods and analysis provided to allow replication by others? Yes

If applicable, is the statistical analysis and its interpretation appropriate?

I cannot comment. A qualified statistician is required.

Are all the source data underlying the results available to ensure full reproducibility? Yes

Are the conclusions drawn adequately supported by the results? Yes

Competing Interests: No competing interests were disclosed. 
Reviewer Expertise: Child and adolescent psychiatry, autism

\section{I confirm that I have read this submission and believe that I have an appropriate level of expertise to confirm that it is of an acceptable scientific standard.}

Reviewer Report 10 August 2017

https://doi.org/10.5256/f1000research.13058.r24874

(c) 2017 Chandradasa $\mathbf{M}$ et al. This is an open access peer review report distributed under the terms of the Creative Commons Attribution License, which permits unrestricted use, distribution, and reproduction in any medium, provided the original work is properly cited.

\section{Miyuru Chandradasa}

1 Department of Psychiatry, Faculty of Medicine, University of Kelaniya, Ragama, Sri Lanka

2 Colombo North Teaching Hospital, Ragama, Sri Lanka

\section{Layani Champika}

Latrobe Regional Hospital, Traralgon, Australia

The publication, Child psychiatry: A scientometric analysis 1980-2016 was read with enthusiasm and admiration. It is true that child and adolescent psychiatry significantly lags behind general adult psychiatry in producing valid clinically useful research. Assessing research output in a scientific field is of utmost importance as it provides a guide for the future development of that field. This article demonstrates the research output trends in child and adolescent psychiatry over the previous four decades. It allows us to generate an understanding of the future research trends and the gaps that should be addressed by researchers in this field.

The mapping of research output in a scientific field is an extremely difficult task. This is made even more cumbersome in the field of child and adolescent psychiatry, as there is an overlap of articles in fields of child psychiatry, child psychology, neuro developmental psychiatry and paediatrics. The authors have employed a sound technique to achieve this complex task by using reputed software such as Web of Science core collection records, Network Analysis Interface for Literature Studies Project scripts and Citespace.

The article highlights the emergence of new concepts in the discipline of child and adolescent psychiatry over the decades. It is interesting to note that some older publications influencing the field after many years from their initial publication.

Few limitations were considered for this publication. The authors have analysed articles of the journals with high impact factor at present. However, it should be noted that in the past different journals had higher impact factors for child and adolescent psychiatry. Many decades back certain reputed journals in general psychiatry published significant numbers of articles in child and adolescent psychiatry as journals dedicated only for this sub speciality were less popular. It is understandable logically that the authors selected the seven journals according to the current impact factors to make this project practical. 
In relevance to the discussion, it would have been interesting to compare some aspects of the results of this study with similar scientometric analyses in other medical disciplines and General Psychiatry. The authors could have concentrated on research output related to aetiology, symptomatology and management compared to other fields of psychiatry and medicine. In future, it would be exciting to compare these results with other sub specialities in psychiatry such as forensic psychiatry, mental health related to intellectual disability, addiction psychiatry and old age psychiatry.

In conclusion, the authors have made a valid and practical attempt to assess and analyse the research output in the discipline of child and adolescent psychiatry over the past four decades. Further scientometric analyses are required to assess the impact of other influential publications in child and adolescent psychiatry published in journals known for general or other specified medical specialities.

Is the work clearly and accurately presented and does it cite the current literature? Yes

Is the study design appropriate and is the work technically sound? Partly

Are sufficient details of methods and analysis provided to allow replication by others? Yes

If applicable, is the statistical analysis and its interpretation appropriate?

I cannot comment. A qualified statistician is required.

Are all the source data underlying the results available to ensure full reproducibility? Yes

Are the conclusions drawn adequately supported by the results? Yes

Competing Interests: No competing interests were disclosed.

We confirm that we have read this submission and believe that we have an appropriate level of expertise to confirm that it is of an acceptable scientific standard. 
The benefits of publishing with F1000Research:

- Your article is published within days, with no editorial bias

- You can publish traditional articles, null/negative results, case reports, data notes and more

- The peer review process is transparent and collaborative

- Your article is indexed in PubMed after passing peer review

- Dedicated customer support at every stage

For pre-submission enquiries, contact research@f1000.com 